\title{
Review
}

\section{Intracavitary Radioimmunotherapy to Treat Solid Tumors}

\author{
Frits Aarts, ${ }^{1}$ Robert P. Bleichrodt, ${ }^{1}$ Wim J.G. Oyen, ${ }^{2}$ and Otto C. Boerman ${ }^{2}$ \\ Departments of ${ }^{1}$ Surgery and ${ }^{2}$ Nuclear Medicine, Radboud University Nijmegen Medical Centre, \\ Nijmegen, The Netherlands
}

\begin{abstract}
Radioimmunotherapy (RIT) potentially is an attractive treatment for radiosensitive early-stage solid tumors and as an adjuvant to cytoreductive surgery. Topical administration of RIT may improve the efficacy because higher local concentrations are achieved. We reviewed the results of locally applied radiolabeled monoclonal antibodies for the treatment of solid tumors. Intracavitary RIT in patients with ovarian cancer and glioma showed improved targeting after local administration, as compared to the intravenous administration. In addition, various studies showed the feasibility of locally applied RIT in these patients. In studies that included patients with small-volume disease, adjuvant RIT in ovarian cancer and glioma showed to be at least as effective as standard therapy. The information about RIT for peritoneal carcinomatosis of colorectal origin is scarce, while results from preclinical data are promising. RIT may be applied for other, relatively unexplored indications. Studies on the application of radiolabeled antibodies in early urothelial cell cancer have been performed, showing that intracavitary RIT may hold a promise. Moreover, in patients with malignant pleural mesothelioma or malignant pleural effusion, RIT may play a role in the palliative treatment. Intracavitary RIT limits toxicity and improves tumor targeting. RIT is more effective in patients with small-volume disease of solid cancers. RIT may have potential for palliation in patients with malignant pleural mesothelioma or malignant pleural effusion. The future of RIT may, therefore, not only be in the inclusion in contemporary multimodality treatment, but also in the expansion to palliative treatment.
\end{abstract}

Key words: radioimmunotherapy, intracavitary, ovarian cancer, glioma, colorectal cancer, urothelial cell cancer

\section{INTRODUCTION}

Address reprint requests to: Frits Aarts; Department of Surgery, Radboud University Nijmegen Medical Centre; P.O. Box 9101, 6500 HB Nijmegen, The Netherlands; Tel.: +31-24-3615333; Fax: +31-24-3540501

E-mail: F.Aarts@chir.umcn.nl
Biologicals play an increasingly important role in the treatment of cancer. Monoclonal antibodies (mAbs) against CD20 are standard therapy in non-Hodgkin's lymphoma (NHL), anti-vas- 
cular endothelial growth factor (VEGF) antibodies are used to treat colon and lung carcinoma and anti-HER2 antibodies play a role in breast cancer treatment. mAbs can also be used to direct anticancer drugs to tumor cells. Drugs, toxins, or radionuclides can be conjugated to mAbs for selective delivery of these agents to tumor tissues, thus sparing normal tissues in contrast to conventional systemic anticancer therapies 1,2

In radioimmunotherapy (RIT), mAbs are labeled with radionuclides to selectively irradiate tumor cells. RIT has proven to be effective in hematologic malignancies but is less effective in solid cancers. ${ }^{3-5}$ Large solid tumors have a limited blood supply, rendering these tumors less accessible for therapeutic agents being delivered via the blood. Impaired blood supply and concomitant ischemia make tumor cells less radiosensitive. ${ }^{6,7}$ In addition, solid tumors have a high interstitial fluid pressure that limits the uptake and penetration of antibodies. ${ }^{8}$ As a result, in large tumors, the uptake of mAbs from the blood is relatively low and heterogeneous, thus limiting the efficacy of RIT. In small tumor lesions, the uptake of mAbs is higher and the heterogeneity of antibody uptake within the tumor can be overcome by the penetration range of the radiation. Therefore, RIT seems to be an attractive adjuvant therapy in small-volume disease or microscopic residual tumor deposits. RIT may also be administered topically in order to reduce systemic activity and enhance tumor targeting. In addition, there are conditions that are particularly suitable for RIT owing to tumor localization (i.e., the development of cancer within a natural cavity) and its concomitant pharmacologic advantages. In both preclinical and clinical studies, the mAb levels in intraperitoneally growing tumors were found to be higher during the first 24 hours after intraperitoneal administration, as compared to systemic administration, thus favoring this route

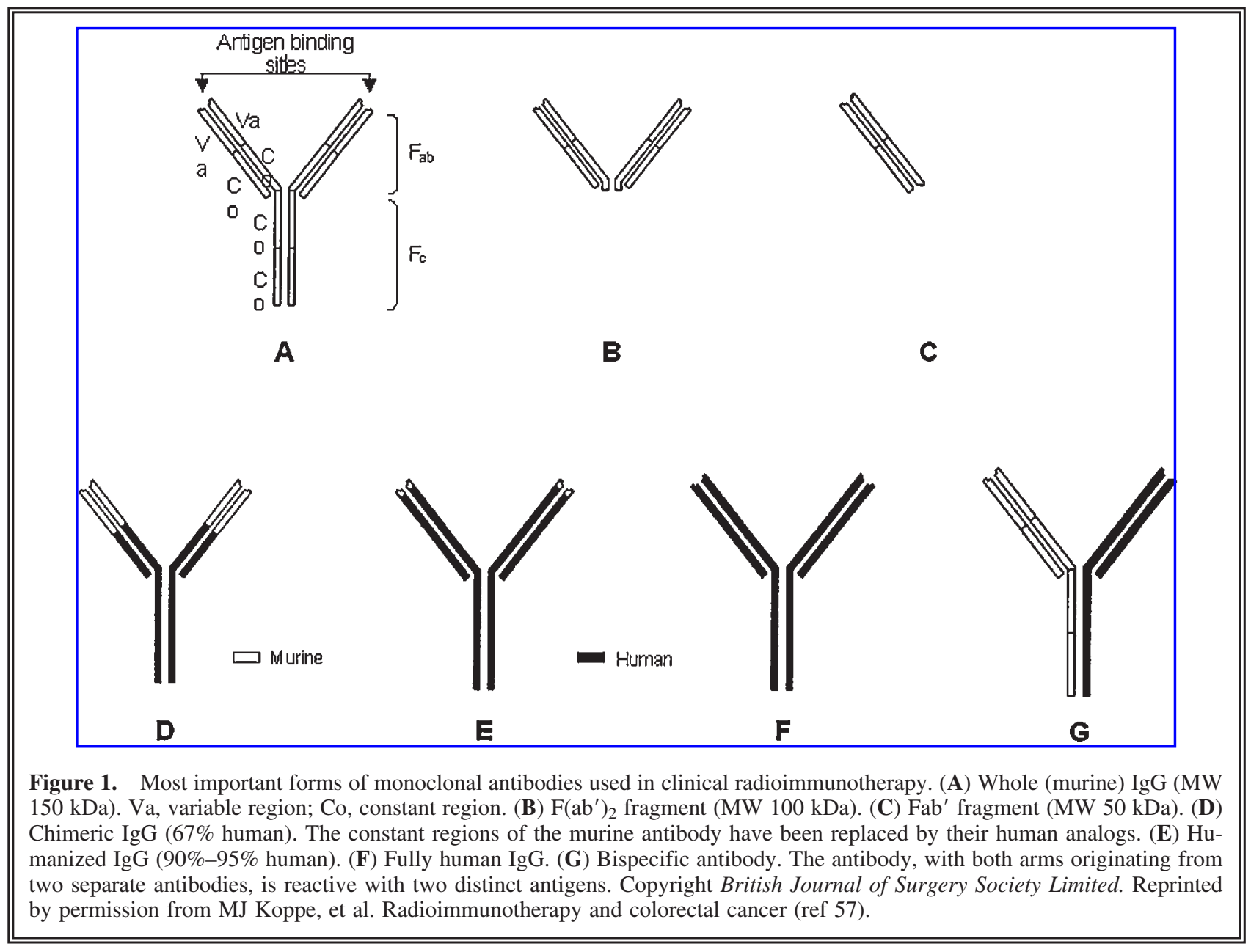


of administration. ${ }^{9,10}$ In this paper, we reviewed the results of locally applied radiolabeled mAbs for the treatment of solid tumors.

\section{RADIOIMMUNOTHERAPY}

\section{Antibodies}

Since the development of the hybridoma technology, it is possible to generate antibodies specifically directed against tumor-associated antigens. ${ }^{11}$ Murine antibodies were the first clinically applied antibodies. A major disadvantage was the production of human antimouse antibodies (HAMAs) that could induce humoral immune responses. In order to reduce immunogenicity, recombinant DNA techniques were applied to produce chimeric and humanized mAbs. ${ }^{12}$ In chimeric $\mathrm{mAbs}$, the variable regions of heavy and light chains are of murine origin, and these are then fused with the constant regions of human origin (Fig. 1). In humanized mAbs, only the Complimentarity Determining Regions (CDR) of the murine origin are grafted in a human antibody framework. ${ }^{13,14}$ To improve in vivo targeting properties, new antibody constructs have been produced, using recombinant DNA techniques (e.g., scFv, minibodies, diabodies, and so forth).

\section{Radionuclides}

The most commonly used radionuclides in RIT are beta-emitters. Beta-particles are electrons that are emitted from the nucleus of an unstable atom. In RIT, iodine-131 $\left({ }^{131} \mathrm{I}\right)$ and yttrium $\left({ }^{90} \mathrm{Y}\right)$ are the most commonly used beta-emitters. More recently, rhenium-186 $\left({ }^{186} \mathrm{Re}\right)$, copper-67 $\left({ }^{67} \mathrm{Cu}\right)$, and lutetium-177 $\left({ }^{177} \mathrm{Lu}\right)$ have also been applied (see Table 1) The differences in physical half-life, the presence or absence of gamma rays, the energy, and consequently the range of the beta-particles in tissue are important with respect to the ra-

\begin{tabular}{|c|c|c|c|c|}
\hline Radionuclide & $\begin{array}{c}\text { Half- } \\
\text { life }\end{array}$ & $\begin{array}{c}\text { Beta } \\
\text { energy } \\
(\mathrm{KeV})\end{array}$ & $\begin{array}{c}\text { Gamma } \\
\text { energy } \\
(\mathrm{KeV})\end{array}$ & $\begin{array}{c}\text { Range } \\
(\beta)\end{array}$ \\
\hline${ }^{131} \mathrm{I}$ & 8 days & 192 & 362 & $3 \mathrm{~mm}$ \\
\hline${ }^{90} \mathrm{Y}$ & 64 hours & 935 & - & $12 \mathrm{~mm}$ \\
\hline${ }^{188} \mathrm{Re}$ & 17 hours & 795 & 155 & $27 \mathrm{~mm}$ \\
\hline${ }^{177} \mathrm{Lu}$ & 7 days & 149 & 208 & $3 \mathrm{~mm}$ \\
\hline${ }^{67} \mathrm{Cu}$ & 62 hours & 141 & 185 & $2 \mathrm{~mm}$ \\
\hline
\end{tabular}

diation dose that can be delivered to the tumor. For example, ${ }^{90} \mathrm{Y}$-labeled mAbs are theoretically not suitable for the treatment of minimal or residual disease with a diameter of only a few millimeters or less, since $70 \%$ of the radiation energy will be deposited outside small tumors (diameter $<5 \mathrm{~mm}$ ) owing to the high energy of the $\beta$-particles (mean, $0.9 \mathrm{MeV}) .{ }^{15}$ For this application, the use of ${ }^{177} \mathrm{Lu}-$ labeled antibodies with medium-energy electron emissions is better suited. ${ }^{16}$ Internalization of the radiolabeled antibodies depends on various factors, including the antibody itself and the targeted antigen. All antibodies eventually are internalized by the target cell and subsequently catabolized. ${ }^{17}$ When internalized, the radiolabeled $\mathrm{mAb}$ is degraded in the lysosomes. In case of radioiodinated $\mathrm{mAbs}$, the radiolabeled metabolites are excreted from the cell. Labeling of mAbs with radiometals, such as ${ }^{90} \mathrm{Y},{ }^{177} \mathrm{Lu}$, and ${ }^{67} \mathrm{Cu}$, is performed by first linking chemical moieties that can complex the metal ions to the antibody (chelators such as DTPA, DOTA, or TETA). When catabolized, the radioactive metabolites of mAbs labeled with radiometals are trapped in the lysosomes, increasing the retention of these radiolabels in the tumor. ${ }^{18,19}$

\section{INTRAPERITONEAL RIT}

The abdominal cavity is lined with mesothelial cells that not only play a role in the sliding of the peritoneal surfaces, but also play an active roll in the immunologic response, inflammation, and coagulation. ${ }^{20}$ Peritoneal clearance is regulated via the peritoneum that behaves as a semipermeable membrane and the lymphatic lacunae underlining diaphragmatic stomata. This clearing process starts within minutes after contamination of the peritoneal cavity.

Antibodies administered into the peritoneal cavity cross the peritoneal lining mainly by diffusion. The rate of diffusion depends on the volume of the instilled agent and the concomitant increase in fluid pressure. ${ }^{21,22}$ Moreover, antibodies will be cleared via the diaphragmatic stomata. For RIT of intraperitoneal lesions, the intraperitoneal (i.p.) administration is advantageous, as compared to the systemic administration, because higher concentrations of the antibody can be reached in the tumor. ${ }^{23}$ When mAbs are administered into the peritoneal cavity, their pharmacokinetics are similar to that of other large-serum proteins. Apart from specific binding to i.p. tumors, there is transportation to the 


\begin{tabular}{|c|c|c|c|c|c|c|c|c|c|}
\hline Author & $\begin{array}{c}\text { No. of } \\
\text { patients }\end{array}$ & $\begin{array}{l}\text { Median } \\
\text { survival } \\
\text { (months) }\end{array}$ & $\begin{array}{l}\text { Tumor- } \\
\text { associated } \\
\text { antigen }\end{array}$ & Antibody & $\begin{array}{l}\text { Stable } \\
\text { disease }\end{array}$ & Remission & $\begin{array}{l}\text { Partial } \\
\text { remission }\end{array}$ & Nuclide & Dose \\
\hline $\begin{array}{l}\text { Epenetos } \\
\text { et al. }\end{array}$ & 24 & & MUC1 & $\begin{array}{l}\text { HMFG1-2, } \\
\text { AUA1, } \\
\text { H17E2 }\end{array}$ & $5 / 24$ & $4 / 24$ & & ${ }^{131} \mathrm{I}$ & $140 \mathrm{mCi}$ \\
\hline $\begin{array}{l}\text { Nicholoson } \\
\text { et al. }{ }^{35}\end{array}$ & 25 & n.r. & MUC1 & HMFG1 & & & & ${ }^{90} \mathrm{Y}$ & $18 \mathrm{mCi} / \mathrm{m}^{2}$ \\
\hline $\begin{array}{l}\text { Epenetos } \\
\text { et al. }^{36}\end{array}$ & 52 & $>52$ & MUC1 & HMFG1 & & $21 / 54$ & & ${ }^{90} \mathrm{Y}$ & \\
\hline $\begin{array}{c}\text { Verheijen } \\
\text { et al. }^{37}\end{array}$ & 224 & & MUC1 & HMFG1 & & & & ${ }^{90} \mathrm{Y}$ & $18 \mathrm{mCi} / \mathrm{m}^{2}$ \\
\hline $\begin{array}{l}\text { Meredith } \\
\text { et al. }{ }^{40}\end{array}$ & 12 & & TAG-72 & CC-49 & & $3 / 12$ & $1 / 12$ & ${ }^{177} \mathrm{Lu}$ & $10-30 \mathrm{mCi} / \mathrm{m}^{2}$ \\
\hline $\begin{array}{l}\text { Rosenblum } \\
\text { et al. }{ }^{41}\end{array}$ & 58 & & TAG-72 & B72.3 & 30 & $2 / 52$ & $2 / 57$ & ${ }^{90} \mathrm{Y}$ & $1-25 \mathrm{mCi}$ \\
\hline $\begin{array}{l}\text { Alvarez } \\
\text { et } \text { al. }^{42}\end{array}$ & 27 & & TAG-72 & CC-49 & 2 & $3 / 27$ & & ${ }^{177} \mathrm{Lu}$ & $10-50 \mathrm{mCi} / \mathrm{m}^{2}$ \\
\hline $\begin{array}{l}\text { Meredith } \\
\text { et al. }{ }^{44}\end{array}$ & 44 & & TAG-72 & CC-49 & $4 / 44$ & & $4 / 44$ & ${ }^{177} \mathrm{Lu}$ & $40-45 \mathrm{mCi} / \mathrm{m}^{2}$ \\
\hline $\begin{array}{l}\text { Alvarez } \\
\text { et al. }{ }^{\mathrm{a}}\end{array}$ & 20 & & TAG-72 & CC-49 & $5 / 20$ & $11 / 20$ & $2 / 20$ & ${ }^{90} \mathrm{Y}$ & \\
\hline $\begin{array}{l}\text { Crippa } \\
\text { et al. }{ }^{46}\end{array}$ & 16 & & GP38 & MOv-18 & & $5 / 16$ & & ${ }^{131} \mathrm{I}$ & $100 \mathrm{mCi}$ \\
\hline $\begin{array}{l}\text { Mahe } \\
\text { et al. }{ }^{47}\end{array}$ & 6 & & CA-125 & OC- -125 & 3 & & & ${ }^{131} \mathrm{I}$ & $120 \mathrm{mCi}$ \\
\hline $\begin{array}{l}\text { Grana } \\
\text { et al. }{ }^{b}\end{array}$ & 16 & & $\begin{array}{l}\text { CEA/TAG- } \\
\text { 72/GP38 }\end{array}$ & n.s. & $5 / 16$ & $1 / 16$ & & ${ }^{90} \mathrm{Y}$ & \\
\hline $\begin{array}{l}\text { Riva } \\
\text { et al.c }\end{array}$ & 10 & & $\begin{array}{l}\text { MUC1 } \\
\text { TAG-72 }\end{array}$ & $\begin{array}{l}\text { HMFG1 } \\
\text { HMFG2 } \\
\text { H17E2 B72.3 }\end{array}$ & & & 3 & ${ }^{131} \mathrm{I}$ & $92 \mathrm{mCi}$ \\
\hline $\begin{array}{l}\text { Jacobs } \\
\text { et al. }^{\text {d }}\end{array}$ & 17 & & PCCA & & & & $4 / 17$ & ${ }^{188} \mathrm{Re}$ & \\
\hline $\begin{array}{r}\text { n.r., not } \mathrm{r} \\
{ }^{\mathrm{a}} \text { Alvarez } \\
\text { dioimmunot } \\
{ }^{\mathrm{b}} \text { Grana C, } \\
\text { geting with } \\
{ }^{\mathrm{c} \text { Riva P, }} \\
\text { Appl Instrur } \\
{ }^{\mathrm{d} J a c o b s ~ A} \\
\text { in ovarian c }\end{array}$ & $\begin{array}{l}\text { ported; n.s } \\
\text { RD, Huh V } \\
\text { terapy for } \\
\text { Bartolome } \\
\text { 90)Y-biotiı } \\
\text { Iarangolo } \\
\text { B 1989;1 } \\
\text { I, Fer M, S } \\
\text { rcinoma: T }\end{array}$ & $\begin{array}{l}\text {, not signif } \\
\mathrm{K} \text {, Khaza€ } \\
\text { varian can } \\
\mathrm{M} \text {, Handk } \\
\text { ? Gynecol } \\
\text {, Lazzari } \\
\text { :659. } \\
\text { FM, et al } \\
\text { oxicity and }\end{array}$ & $\begin{array}{l}\text { ficant. } \\
\text { eli MB, et al. } \\
\text { cer. Clin Cance } \\
\text { xiewicz D, et al } \\
\text { Oncol 2004;93 } \\
\text { S, et al. Locore } \\
\text { A phase I tria } \\
\text { clinical respor }\end{array}$ & $\begin{array}{l}\text { Phase I study } \\
\text { Res 2002;8:28 } \\
\text { Radioimmunoth } \\
691 . \\
\text { ional immunoth } \\
\text { of a rhenium } 18 \\
\text { se. Obstet Gyne }\end{array}$ & $\begin{array}{l}\text { of combi } \\
06 . \\
\text { herapy in } \\
\text { erapy of } 1 \\
\text { 86-labeled } \\
\text { col } 1993 \text {; }\end{array}$ & $\begin{array}{l}\text { ined modalit } \\
\text { advanced ov } \\
\text { human ovaric } \\
\text { monoclonal } \\
82: 586 \text {. }\end{array}$ & $\begin{array}{l}\text { (90)Yttriu } \\
\text { arian cancer } \\
\text { n cancer: Pr } \\
\text { antibody ad }\end{array}$ & $\begin{array}{l}\text { n-CC49 in } \\
\text { Is there a } \\
\text { eliminary } r \\
\text { ministered }\end{array}$ & $\begin{array}{l}\text { traperitoneal ra- } \\
\text { role for pre-tar- } \\
\text { esults. Int J Rad } \\
\text { intraperitoneally }\end{array}$ \\
\hline
\end{tabular}

circulation and subsequent uptake in normal tissues. ${ }^{24,25}$ However, in both preclinical and in clinical studies, the concentration of mAbs in the tumor lesions is higher during the first 24 hours after an i.p. administration while blood levels are lower, as compared to a systemic administration. In addition, not only the tumor uptake is increased, but also the tumor:nontumor ratio. This favors this route of administration for i.p. growing tumors. ${ }^{10,26}$

\section{Ovarian Cancer}

Ovarian cancer mostly originates from the surface epithelium of the ovaries, and in most patients, metastases are confined to the peritoneal cavity without further distant metastases. ${ }^{27}$ The overall survival rate is $35 \%$. The majority of patients presents with advanced disease at the time of diagnosis. Radical debulking, in combination with platinum- or taxol-based chemotherapy, is 
the standard treatment, resulting in $50 \%$ local recurrences and a median survival of 2 years. ${ }^{28,29}$

Ovarian cancer seems to be well suited for i.p. administered adjuvant RIT. ${ }^{30}$ The disease has been targeted by using antibodies directed against tumorassociated antigens as the mucin-1 (MUC1) antigen, CA-125, TAG-72, and gp38 (see Table 2).

As mentioned above, several preclinical and clinical studies demonstrated that an i.p. administration of RIT resulted in a higher uptake of radiolabeled antibodies in tumor, as compared to systemic route administration. ${ }^{10,26,31,32}$

\section{MUC-1}

MUC-1 is expressed on glandular epithelium in the majority of adenocarcinomas, including breast, ovary, and pancreas, where it is both overexpressed as well as aberrantly glycosylated. ${ }^{33}$ One of the first RIT trials in patients with ovarian cancer was carried out by Epenetos et al., treating 24 patients with stage III ovarian cancer in an adjuvant setting to cytoreductive surgery and platinum-based chemotherapy. In this study, ${ }^{131}$ I-labeled anti-MUC1 mAbs, HMFG1-2, AUA 1, and H17E2, were used. ${ }^{34}$ The best response was found in the 16 patients with minimal or small-volume $(<2 \mathrm{~cm}$ diameter $)$ disease. No response was seen in the 8 patients with largevolume disease $(>2 \mathrm{~cm}$ diameter) who all died of recurrent disease within 9 months. In another trial, the efficacy of adjuvant ${ }^{90}$ Y-labeled HMFG1 following surgery and chemotherapy was compared to a historic control group that was treated with surgery and chemotherapy alone. Five (5)-year survival in the RIT group was $80 \%$, as compared to $55 \%$ in the control group. ${ }^{35}$ Later, these investigators reported that after 12 years of follow-up, the median survival of a group with complete remission following surgery, chemotherapy, and adjuvant ${ }^{90} \mathrm{Y}-\mathrm{HMFG} 1$ had not yet been reached. These results were better than the results in a historic control group that had a median survival of $42 \%$ survival after 5 years of follow-up. ${ }^{36}$ Based on the encouraging results of these phase I/II studies, a phase III open-label, randomized, multicenter phase III trial was undertaken. This study included patients to be treated with ${ }^{90} \mathrm{Y}$-HMFG1 RIT (maximum dose, $25 \mathrm{mCi} ; N=224$ ) and compared them to conventionally treated patients $(N=223) .{ }^{37}$ Patients were eligible after a complete clinical response to platinum-based chemotherapy following surgical cytoreduction. Intraperitoneally administered RIT was applied after a confirmed mac- roscopically negative laparoscopy. This study failed to show a benefit in overall survival or a prolonged disease-free survival after RIT. Although peritoneal recurrence was significantly delayed in the RIT group, extraperitoneal metastases, mainly located in the para-aortic lymph nodes, were found more frequently than in the control group ( $49 \%$ versus $14 \%) .38$

\section{TAG-72}

TAG-72 is a mucin-like antigen that is heterogeneously expressed in virtually all ovarian cancers. The pharmacology, metabolism, and tissue distribution of ${ }^{90}$ Y-labeled anti-TAG-72 B72.3 was investigated in 9 patients with ovarian cancer. ${ }^{39}$ Following this report, Meredith et al. ${ }^{40}$ and Rosenblum et al. ${ }^{41}$ performed i.p. RIT studies in patients with chemotherapy-resistant or refractory ovarian cancer limited to the peritoneal cavity. Rosenblum et al. included 58 patients treated with ${ }^{90}$ Y-labeled B72.3, 1-25 mCi, resulting in 2 complete remissions and 30 patients with stable disease with a median of 6 months (range, 4-24). In a study using ${ }^{177} \mathrm{Lu}$-labeled CC49, a secondgeneration anti-TAG-72 antibody with a higher affinity for TAG-72 than the B72.3 antibody (dose, $10-50 \mathrm{mCi} / \mathrm{m}^{2}$ ), Alvarez et al. included 27 patients. Fourteen (14) of these patients with small $(<1 \mathrm{~cm})$ or microscopic disease were stable for 6-35 months, whereas in patients with measurable disease $(>1 \mathrm{~mm})$, only 1 patient showed a partial response. The other patients showed progression within 3 months. ${ }^{42}$ Meredith et al. published a report including 12 patients treated with ${ }^{177} \mathrm{Lu}$-labeled CC49, 10-30 $\mathrm{mCi} / \mathrm{m}^{2}{ }^{40}$ This resulted in complete remission in 3 patients and stable disease in 1. Complete responses were only found in patients with microscopic disease. Following the report by Roselli et al., ${ }^{43}$ who showed that interferon (IFN) enhances the expression of TAG-72, Meredith et al. subsequently tested the feasibility and efficacy of a combination of subcutaneous (s.c.) injections of IFN, i.p. paclitaxel $\left(100 \mathrm{mg} / \mathrm{m}^{2}\right)$, and RIT consisting of $40-45 \mathrm{mCi} / \mathrm{m}^{2}{ }^{177} \mathrm{Lu}$-labeled CC49. This study included 44 patients with ovarian cancer, 27 of whom had only microscopic disease or disease not measurable on computed tomography (CT) ${ }^{44}$ Four (4) of 17 patients with macroscopic disease on CT showed a partial response (decrease of $>50 \%$ diameter), whereas 4 of 27 patients with microscopic disease showed progression-free time intervals of more than 18 months. Subsequently, the same research group treated 20 
patients with persistent or recurrent ovarian cancer after conventional cytoreductive surgery and chemotherapy, with a combination of RIT using ${ }^{90} \mathrm{Y}$ labeled CC49 and a single i.p. administered dose of paclitaxel $\left(100 \mathrm{mg} / \mathrm{m}^{2}\right)$ and IFN. In 3 of 11 patients with nonmeasurable disease, disease-free survival was more than 18 months. The researchers concluded that this combination of treatments was well tolerated and showed antitumor activity.

\section{gp38}

MOv18 is an antibody directed against the folate receptor gp38, which is expressed at high levels in $90 \%$ of serous ovarian carcinomas. The expression level on other epithelial tissues is low. ${ }^{45}$ The murine MOv18 mAb is highly immunogenic, inducing human antimouse antibodies (HAMA) in most patients. MOv18 targeting of ovarian cancer was investigated by van Zanten-Przybysz et al. ${ }^{26}$ by comparing the i.p. administration to the intravenous (i.v.) injection. Ex vivo measured tumor uptake after i.p. administration was 3.4\%$12.3 \%$, whereas this was $3.6 \%-5.4 \%$ after the i.v. administration. ${ }^{32}$ In addition, van Zanten-Przybysz et al. determined the pharmacokinetics and tumor accumulation of both i.v. and i.p. administered cMOv18 in the same patient in a dual-label ${ }^{125 / 131}$ I-study in 15 patients. They showed a tumor uptake of $4.9 \%$ and $2.4 \%$ injected dose per kilogram (ID $/ \mathrm{kg}$ ) after the i.v. and i.p administration after 2 days, respectively. After 6 days, there was no difference in tumor uptake between the routes of administration $(3.8 \%$ and $3.9 \% \mathrm{ID} /$ $\mathrm{kg}$ for i.v. and i.p). Moreover, the mean AUC for the blood-activity versus time curve was 3.5 times higher after the i.v injection at 2 days and 2.1 times higher at 6 days, as compared to the i.p injection. The researchers, therefore, concluded that the i.p. route could be advantageous owing to the significantly lower bone marrow toxicity as a result of lower blood levels of the radiolabeled antibody when administered i.p. ${ }^{26}$

Crippa et al. tested the efficacy of i.p. administered RIT, using ${ }^{131} \mathrm{I}-\mathrm{MOv} 18$ (mean dose, 100 $\mathrm{mCi}$ ) in 16 patients with minimal or small-volume ovarian cancer. ${ }^{46}$ Clinical follow-up and/or third-look evaluation performed 90 days after the administration of RIT showed a complete response in 5 , stable disease in 6 , and progressive disease in 5 patients. Of the 5 patients that showed a complete response, 1 patient remained disease free after a follow-up of 34 months, whereas the remaining 4 patients relapsed after a mean period of 10.5 months.

\section{CA-125}

Mahe et al. performed a phase I study comprising of i.p. administered $120 \mathrm{mCi}$ of the ${ }^{131}$ I-labeled anti-CA-125 antibody OC125 to 6 patients with residual macroscopic $(<5 \mathrm{~mm})$ or microscopic disease, resulting in stable disease in 2 patients. ${ }^{47}$ In addition, there was HAMA formation in all 6 patients. The reported lack of efficacy might be owing to the nature of CA-125, being a antigen that is shed from the cell membrane. ${ }^{48,49}$

In conclusion, the data available on the use of adjuvant i.p. RIT in patients with ovarian cancer show improved targeting after the i.p. administration, as compared to the i.v. administration. Despite the lack of survival benefit, the phase III study with ${ }^{90}$ Y-HMFG1 showed an improved local control of i.p. disease in patients treated with RIT.

\section{Colorectal Cancer}

Colorectal cancer (CRC) may spread intraperitoneally, causing peritoneal carcinomatosis (PC). In $25 \%$ of the patients with recurrent CRC, this is the only site of metastasis. ${ }^{50}$ If untreated, patients suffering from PC have a median survival of only 6 months. ${ }^{51}$ Today's gold standard for the treatment of PC is cytoreductive surgery, followed by heated i.p. chemotherapy or HIPEC. ${ }^{50}$ This highly specialized, extensive treatment is associated with a high morbidity (14\%-55\%) and high mortality (19\%). ${ }^{50}$ Although the results of this treatment are promising, the median survival is $13-34$ months $^{52,53}$ and the 5-year survival rate is $19 \%-27 \% .{ }^{54,55}$ Owing to the high complication rates, there is a need for new treatment modalities.

RIT for CRC has been under clinical investigation since 1992, mainly with anti-carcinoembryonic antigen (CEA) antibodies. ${ }^{56}$ The results of RIT in CRC were recently reviewed by our group. ${ }^{57}$ So far, only one trial gave the results of i.p. administered RIT in patients with advanced CRC. Patients with local as well as regional and systemic spread were included. ${ }^{58}$ Thirty-one (31) patients with large peritoneal metastases were treated. Patients received 5 cycles of i.p. administered ${ }^{131}$ I-labeled anti-CEA/TAG-72/MUC-1. This was done either as monotherapy (one antibody) or in combination with multiple antibodies. The average activity dose per cycle was 98 $\mathrm{mCi}$. The researchers reported a median survival of 41 months, complete remission lasting 23 months in 10 patients, stable disease that lasted 
for 12 months in 8 patients, and a partial remission in 10 patients.

Preclinical studies in mice with colon cancer xenografts were performed by Keenan et al. as early as 1984, suggesting RIT might be successful for the treatment of colon cancer in humans. ${ }^{59}$ The preclinical as well as the clinical investigations of this group focussed on the i.v. route of administration, despite a more efficient tumor targeting in patients with PC after a i.p. administration than after an i.v. administration, as shown in a dual-label study of concomitant i.v.- and i.p.administered ${ }^{131}$ I-labeled B72.3. ${ }^{10}$

In nude mice with i.p. growing human colon carcinoma, the i.p. route of administration of radiolabeled MN14, an anti-CEA antibody, showed a higher tumor uptake during the first -48 hours $(58.5 \% \pm 6.8 \% \mathrm{ID} / \mathrm{g}$ for i.p. vs. $34.9 \% \pm 4.7 \%$ ID/g for i.v.) after administration. Thereafter, the uptake was similar. ${ }^{60}$ In addition, an increased therapeutic efficacy of ${ }^{177} \mathrm{Lu}$-(median survival, 136 days) and ${ }^{131}$ I-labeled MN14 (median, 100 days) was reported, when compared to equitoxic doses (8.33 MBq) of ${ }^{90} \mathrm{Y}$-(median, 82 days) and ${ }^{186}$ Re-labeled MN14 (median, 72 days) in this model. ${ }^{61}$ The feasibility of i.p. RIT in an adjuvant setting to cytoreductive surgery, leaving only microscopic disease, was also investigated by Koppe et al. The researchers used ${ }^{177} \mathrm{Lu}$-labeled MG1, a radiolabeled anti-CC531 (rat colon carcinoma) antibody administered after cytoreductive surgery (CS). In this model, adjuvant RIT resulted in a significantly improved survival of rats treated with the combination of CS and RIT, as compared to either CS or RIT alone. ${ }^{62}$ Despite these favorable preclinical studies, there are no clinical trials investigating the efficacy of RIT as an adjuvant treatment to cytoreductive surgery for peritoneal carcinomatosis of colorectal origin.

In conclusion, RIT is an effective treatment for i.p. metastases and an effective adjuvant to cytoreductive surgery in preclinical studies. The limited experience in phase I clinical trials warrants clinical studies.

\section{RIT IN BRAIN TUMORS}

An estimated 41,000 cases of primary central nervous system (CNS) tumors occur annually in the United States, $42 \%$ of which are glial tumors that are, in most cases, malignant. ${ }^{63}$ Glioblastoma multiforme, the most malignant form of CNS tumors, offers patients a very poor overall survival of only $3.3 \%$ after 2 years, despite the combination of surgery, radiotherapy, and chemotherapy. ${ }^{64}$ More than $90 \%$ of all recurrences are adjacent to the site of origin, indicating a failure of local tumor control. Conventional radiotherapy plays a primary role in brain cancer treatment. However, its lack of tumor specificity is a significant limitation of this form of therapy. Owing to its nonspecific nature, toxicity to normal brain limits the radiation dose that can be delivered to tumor cells and compromises the quality of life of the few longer term survivors. There are three factors responsible for treatment failure: (1) the delivery of therapeutic agents is limited by the blood-brain barrier (BBB), despite the fact that it is disrupted in regions of macroscopic tumor ${ }^{65}$; (2) dysfunctional tumor vasculature, as is the case in most solid tumors, leads to local hypoxia and a reduced responsiveness to chemoand radiotherapy in combination with an elevated intratumoral interstitial pressure ${ }^{66-68}$; (3) interand intratumoral cellular and genetic heterogeneity, leading to heterogeneous antigen expression. ${ }^{69,70}$

In general, adjuvant treatment consists of the use of local radiation by means of stereotactic radiotherapy or brachytherapy with implanted ${ }^{125} \mathrm{I}$ rods. However, these approaches did not show additional effects on survival. ${ }^{71,72}$ Recent applications of combinations of chemotherapy (temozolomide) with radiotherapy showed a survival benefit. The majority of patients, however, died within 1-2 years from progressive disease, underlining the need for new treatment strategies. ${ }^{73}$

The $\mathrm{BBB}$ regulates the exchange of substances between the vasculature and the CNS. This physiologic barrier is composed of tight junctions between the capillary endothelial cells and is supported by a microenvironment of astrocytes, pericytes, and microglial cells. ${ }^{74}$ This almost impenetrable barrier prohibits the delivery of potentially effective therapeutic agents, thereby limitating the treatment of CNS diseases. In the case of malignant disease, the deterioration of the BBB may occur, which may improve the delivery of therapeutic agents to the CNS. Brain tumors can cause a complete breakdown of the BBB, eventually leading to peritumoral, vasogenic edema. ${ }^{74}$ Imaging of CNS malignancies, using radiolabeled antibodies, showed intratumoral accumulation following the i.v. administration, allowing for scintigraphic imaging. This indicates damage to the BBB. However, in general, there is insufficient targeting for therapeutic studies. ${ }^{75}$ 


\begin{tabular}{|c|c|c|c|c|c|c|c|c|c|c|}
\hline Author & $\begin{array}{c}\text { No. of } \\
\text { patients }\end{array}$ & Indication & $\begin{array}{c}\text { Tumor- } \\
\text { associated } \\
\text { antigen }\end{array}$ & Antibody & $\begin{array}{l}\text { Median } \\
\text { survival } \\
\text { (months) }\end{array}$ & $\begin{array}{l}\text { Stable } \\
\text { disease }\end{array}$ & Remission & $\begin{array}{c}\text { Partial } \\
\text { remission }\end{array}$ & Nuclide & Dose \\
\hline Bigner et al. ${ }^{81}$ & 42 & GB/AA/AO & $\mathrm{TN}$ & $81 \mathrm{C6}$ & & & & & ${ }^{131} \mathrm{I}$ & $100 \mathrm{mCi}$ \\
\hline Cokgor et al. ${ }^{83}$ & 42 & GB/AA/AO & $\mathrm{TN}$ & $81 \mathrm{C6}$ & 20 weeks & $4 / 42$ & & & ${ }^{131} \mathrm{I}$ & $20-180 \mathrm{mCi}$ \\
\hline $\begin{array}{l}\text { Reardon } \\
\text { et al. }^{84}\end{array}$ & 33 & GB/AA/AO & $\mathrm{TN}$ & $81 \mathrm{C} 6$ & $79-85$ weeks & 0 & n.r. & n.r. & ${ }^{131} \mathrm{I}$ & $120 \mathrm{mCi}$ \\
\hline $\begin{array}{l}\text { Reardon } \\
\text { et al. }{ }^{85}\end{array}$ & 43 & GB/AA/AO & $\mathrm{TN}$ & $81 \mathrm{C} 6$ & 69 weeks & 0 & 0 & 0 & ${ }^{131} \mathrm{I}$ & $120 \mathrm{mCi}$ \\
\hline $\begin{array}{l}\text { Reardon } \\
\text { et al. }{ }^{86}\end{array}$ & 47 & GB/AA/AO & $\mathrm{TN}$ & ch81C6 & 89 weeks & & & & ${ }^{131} \mathrm{I}$ & $\leq 80-100 \mathrm{mCi}$ \\
\hline Riva et al. ${ }^{88}$ & 10 & GB & $\mathrm{TN}$ & $\mathrm{BC}-2 / 4$ & & $3 / 10$ & $1 / 10$ & $2 / 10$ & & $15 \mathrm{mCi}$ \\
\hline Riva et al. ${ }^{90}$ & 50 & GB & $\mathrm{TN}$ & BC- $2 / 4$ & 20 months & $11 / 50$ & $3 / 50$ & $6 / 50$ & ${ }^{131} \mathrm{I}$ & \\
\hline Riva et al. ${ }^{91}$ & 111 & GB/AA/AO & $\mathrm{TN}$ & BC- $-2 / 4$ & 19 months & 10 & 1 & 9 & ${ }^{131} \mathrm{I}$ & $70 \mathrm{mCi}$ \\
\hline Riva et al. ${ }^{\mathrm{a}}$ & 23 & GB & $\mathrm{TN}$ & BC-2/4 & 16 months & $5 / 23$ & $3 / 23$ & $3 / 23$ & ${ }^{131} \mathrm{I}$ & $15-57 \mathrm{mCi}$ \\
\hline Riva et al. ${ }^{\mathrm{b}}$ & 20 & GB/AA & $\mathrm{TN}$ & BC-4 & n.r. & 0 & 0 & 0 & ${ }^{90} \mathrm{Y}$ & $5-30 \mathrm{mCi}$ \\
\hline $\begin{array}{l}\text { Mamelak } \\
\text { et al. }^{\mathrm{c}}\end{array}$ & 19 & GB/AA & $\mathrm{TN}$ & TM-601 & 27 weeks & & & & ${ }^{131} \mathrm{I}$ & $10 \mathrm{mCi}$ \\
\hline Riva et al. ${ }^{\mathrm{b}}$ & 17 & GB & & & & & $3 / 17$ & $3 / 17$ & & \\
\hline $\begin{array}{l}\text { Pöpperl } \\
\text { et al. }^{\text {d }}\end{array}$ & 24 & GB/AA & $\mathrm{TN}$ & & $12-87$ & & $7 / 24$ & & ${ }^{131} \mathrm{I} /{ }^{188} \mathrm{Re}$ & 150-13 Mci \\
\hline Goetz et al. ${ }^{\mathrm{e}}$ & 37 & GB/AA & TN & & 17 & n.r. & n.r. & n.r. & ${ }^{131} \mathrm{I} /{ }^{90} \mathrm{Y}$ & \\
\hline $\begin{array}{l}\text { Paganelli } \\
\text { et al. }{ }^{33}\end{array}$ & 24 & GB/AA & $\mathrm{TN}$ & BC-4 & $11 / 19$ & $12 / 24$ & & $6 / 24$ & ${ }^{90} \mathrm{Y}$ & $15-30 \mathrm{mCi}$ \\
\hline $\begin{array}{l}\text { Papanastassiou } \\
\text { et al. }{ }^{\mathrm{f}}\end{array}$ & 7 & Glioma & NCAM & ERIC-1 & n.r. & n.r. & n.r. & n.r. & ${ }^{131} \mathrm{I}$ & \\
\hline 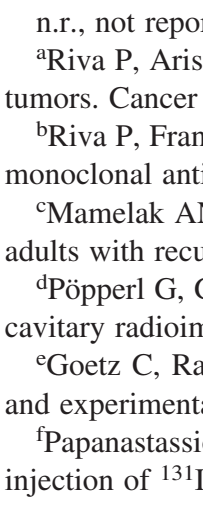 & $\begin{array}{l}\text { rted. } \\
\text { ta A, Tisc } \\
\text { 1994;73: } \\
\text { iceschi G, } \\
\text { ibodies la } \\
\text { N, Rosenf } \\
\text { urrent higl } \\
\text { Gotz C, R } \\
\text { nmunothe } \\
\text { achinger V } \\
\text { al finding } \\
\text { lou V, Piz } \\
\text { I monoclo }\end{array}$ & $\begin{array}{l}\text { on V, et al. I } \\
\text { :1076. } \\
\text {, Frattarelli } \mathrm{N} \\
\text { abeled with } \\
\text { ffeld S, Buch } \\
\text { h-grade glior } \\
\text { Rachinger W, } \\
\text { erapy in patie } \\
\text { W, Poepperl } \\
\text { gs. Acta Neur } \\
\text { zer BL, Coak } \\
\text { onal antibody }\end{array}$ & $\begin{array}{l}\text { Intralesional } \\
\text { M, et al. Lo } \\
{ }^{0} \text { Y: A phas } \\
\text { olz R, et al } \\
\text { ma. J Clin } \\
\text { et al. Seria } \\
\text { ents with m } \\
\text { G, et al. In } \\
\text { rochir Supp } \\
\text { yam HB, et } \\
\text { y: Feasibilit }\end{array}$ & $\begin{array}{l}\text { 1 radioimm } \\
\text { co-regional } \\
\text { se I study. } \\
\text { I. Phase I s } \\
\text { Oncol } 2006 \\
\text { al O-(2-[(18 } \\
\text { alignant gl } \\
\text { tralesional } \\
\text { l 2003;88: } \\
\text { t al. Treatn } \\
\text { y, pharmac }\end{array}$ & $\begin{array}{l}\text { nunotherapy o } \\
\text { l radioimmun } \\
\text { Clin Cancer } \mathrm{P} \\
\text { single-dose stu } \\
6 ; 24: 3644 \text {. } \\
8) \text { F]fluoroethy } \\
\text { lioma. Eur J } ~ \\
1 \text { radioimmun } \\
\text { :69. } \\
\text { ment of recurr } \\
\text { cokinetics and }\end{array}$ & $\begin{array}{l}\text { f malign: } \\
\text { otherapy } \\
\frac{\text { Res } 1999}{\text { udy of in }} \\
\text { yl)-L: -Ty } \\
\text { Nucl Med } \\
\text { otherapy } \\
\text { rent and c } \\
\text { d dosimet }\end{array}$ & $\begin{array}{l}\text { ant gliomas } \\
\text { of high-gra } \\
; 5: 3275 \mathrm{~s} \text {. } \\
\text { tracavitary- } \\
\text { yrosine PET } \\
\text { d Mol Imag } \\
\text { in the treat } \\
\text { cystic malig } \\
\text { try. Br J Ca }\end{array}$ & $\begin{array}{l}\text { An effect } \\
\text { ade malign } \\
\text {-administer } \\
\text { T for moni } \\
\text { tment of } \mathrm{m} \\
\text { gnant glion } \\
\text { ancer 1993 }\end{array}$ & $\begin{array}{l}\text { tive treatme } \\
\text { ant gliomas } \\
\text { red iodine-1 } \\
\text { toring the e } \\
33: 792 \text {. } \\
\text { nalignant gl } \\
\text { nas by a sin } \\
; 67: 144 \text {. }\end{array}$ & $\begin{array}{l}\text { ent in recurrent } \\
\text { s using specific } \\
\text { 131-TM-601 in } \\
\text { effects of intra- } \\
\text { ngle intracavity }\end{array}$ \\
\hline
\end{tabular}

To overcome the problem of limited penetration, the locoregional application of therapeutic agents in patients with malignant glioma has been investigated. ${ }^{76}$ To investigate the application of RIT, candidates for therapy, or tumor-associated antigens (TAAs), needed to be identified.

\section{Tenascin-c}

In the majority of clinical RIT studies in glioma patients, antitenascin mAbs were used. m81C6, a murine IgG2b with affinity for tenascin-c (TN), has been administrated through a s.c. implanted reservoir connected to an intracavitary-placed drain. TN is an extracellular matrix protein modulating cell-matrix interactions, ${ }^{77}$ which is overexpressed in malignant glioma tissue, but not expressed in the normal brain. The distribution and intensity of TN expression correlates well with tumor neovasculature and shows evident expression in aggressive histotypes as well as in those tumors with high proliferation indices. ${ }^{78-80}$ This distribution of TN makes it a suitable target in RIT in glioma (see Table 3). 
A series of phase I-III studies has been conducted at Duke University. In the first phase I study, 42 patients with recurrent glioma were included and the maximal tolerable dose (MTD) was assessed in a dose-escalation study after intracavitary (into the surgically created cavity; SCC) administration. This study showed that the MTD was $100 \mathrm{mCi}$ for intracavitary-administered ${ }^{131}$ I-labeled $81 \mathrm{C} 6$, with neurotoxicity being the dose-limiting factor. ${ }^{81}$ The results of this study suggested that there was a potential survival benefit, as compared to patients treated with stereotactic radiotherapy and high-dose brachytherapy (a median survival of 60 weeks in the present study, as compared to 41 and 46 weeks, respectively). In the second study, 42 patients with newly diagnosed glioma were included in order to investigate dosimetry and doseresponse relationships. ${ }^{82,83}$ In these patients, the MTD was $120 \mathrm{mCi}$, with neurotoxicity being the dose-limiting factor. The median survival of these patients was 79 weeks, as compared to 46 weeks of historic controls, when patients were treated with surgery, chemotherapy, and radiotherapy. Based on these encouraging results, a phase II trial was performed in 33 patients with newly diagnosed, previously untreated patients. The median survival after treatment with 120 mCi of ${ }^{131}$ I-labeled 81C6 in this study was 79-85 weeks, depending on the pathologic type of glioma (patients with astrocytic oligodendroglioma showed a better response than those with glioblastoma multiforme). ${ }^{84}$ When $100 \mathrm{mCi}$ of radiolabeled antibody was administered to 43 patients with recurrent glioma, survival was still 69 weeks. ${ }^{85}$ The results of these trials warranted a phase III trial, which is currently ongoing.

Recently, a human/mouse chimeric mAb, originating from $81 \mathrm{C} 6$, has been developed, showing better tumor targeting in animal studies. The targeting capabilities of the antibody were subsequently tested in a phase I study that included 47 patients with recurrent disease. ${ }^{86}$ This chimeric antibody showed a prolonged retention time within the SCC, as compared to the antibody of murine origin. Owing to the enhanced circulatory half-life of the chimeric antibody, a MTD of $80 \mathrm{mCi}$ was found, as compared to $120 \mathrm{mCi}$ found in previous studies with the murine antibody. In this phase I dose-escalation study, the median survival was 87 weeks for patients with newly diagnosed glioma and 65 weeks for those patients with recurrent disease.

Riva et al. used another anti-tenascin antibody labeled with ${ }^{131} \mathrm{I}, \mathrm{BC}-2 / 4$, initially injected directly into the tumor. ${ }^{87}$ Thereafter, the antibody was, in some patients repeatedly, administered into the SCC in 23 patients with recurrent glioblastoma. In their first report, no toxicity and an objective response in 11 patients, in whom were 3 complete remissions and a median survival of 16 months, were reported. ${ }^{88}$ The follow-up study compared the results of antibody administration in recurrent and newly diagnosed patients. ${ }^{89}$ The reported total median survival was 20 months. When bulky (median, 17 months) versus minimal disease (median, 26 months) were compared, the results supported the concept that RIT is most suitable in patients with small-volume disease. Later, combined data of 111 patients that were included in phase I and II studies showed a median survival of 20 months. ${ }^{90}$ The researchers concluded that the application of RIT is most suitable in small-volume disease. In a following phase I study, ${ }^{91}$ the researchers switched to the application of an other radionuclide, ${ }^{90} \mathrm{Y}$, in 20 patients and determined the MTD to be $25 \mathrm{mCi}$ with neurotoxicity as the dose-limiting toxicity. No diffusion of the radiolabeled antibody to normal tissue was reported. However, this study failed to show clinical responses, presumably owing to the inclusion of patients with advanced disease.

Paganelli et al. ${ }^{92,93}$ investigated the use of the pretargeting technique consisting of the biotinylated antitenascin MAb $\mathrm{BC} 4$, avidin and ${ }^{90} \mathrm{Y}$-biotin, both i.v. administered as well as directly into the SCC, following surgical debulking. In this pretargeting approach, the large IgG-avidin conjugate was administered first, followed by a ${ }^{90} \mathrm{Y}$-labeled biotin injection. These studies showed no hematologic toxicity following the RIT when applied into the SCC, as compared to almost all the other studies that used mAbs, including the study where pretargeting was used and administered i.v. This latter study supports the local administration technique by showing a total body distribution of the biotinylated $\mathrm{mAb}$ and fast blood clearance within hours after the i.v. administration.

To summarize, the phase I-II studies from Duke University on the use of adjuvant RIT after debulking surgery in patients with malignant glioma indicate an improved survival, as compared to historic control groups. In addition, there was a reduction in treatment-related toxicity, compared to stereotactic radiotherapy or brachy therapy. This resulted in a phase III trial that is currently ongoing. The results from Riva et al., despite the more heterogeneous group of patients, support this conclusion. 


\begin{tabular}{|c|c|c|c|c|c|c|}
\hline Author & $\begin{array}{c}\text { No. of } \\
\text { patients }\end{array}$ & Indication & $\begin{array}{l}\text { Tumor- } \\
\text { associated } \\
\text { antigen }\end{array}$ & Antibody & Nuclide & Targeting \\
\hline Bamias et al. ${ }^{98}$ & 21 & SUC & MUC1 & HMFG2 & ${ }^{111} \mathrm{In}$ & + \\
\hline Simms et al. ${ }^{\mathrm{a}}$ & 21 & $\begin{array}{l}\text { SUC-T2-metastatic } \\
\text { invasive bladder } \\
\text { cancer }\end{array}$ & MUC1 & C595 & ${ }^{99 \mathrm{~m}} \mathrm{Tc}$ & $16 / 20$ \\
\hline Murray et al. ${ }^{99}$ & 5 & TCC & MUC1 & C595 & ${ }^{188} \mathrm{Re}$ & $4 / 5$ \\
\hline Hughes et al. ${ }^{100}$ & 16 & SUC-T2 & MUC1 & C595 & ${ }^{67} \mathrm{Cu}$ & $12 / 16$ \\
\hline Malamitsi et al. ${ }^{101}$ & 15 & SUC & MUC1 & HMFG1 & ${ }^{99 \mathrm{~m}} \mathrm{Tc} /{ }^{131} \mathrm{I}$ & \pm \\
\hline Chinol et al. ${ }^{b}$ & 12 & TCC & n.r. & Avidin & ${ }^{99 \mathrm{~m}} \mathrm{Tc}$ & $10 / 12$ \\
\hline Syrigos ${ }^{c}$ & 6 & SUC & MUC1 & HMFG1 & ${ }^{131} \mathrm{I}$ & $4 / 6$ \\
\hline Kunkler et al. ${ }^{\mathrm{d}}$ & 12 & SUC & MUC1 & NCRC48 & ${ }^{111} \mathrm{In}$ & + \\
\hline \multicolumn{7}{|c|}{$\begin{array}{l}\text { n.r., not reported. } \\
\text { aSimms MS, Perkins AC, Price MR, et al. }{ }^{99 m} \text { Technetium-C595 radioimmunoscintigraphy: A potential staging tool for blad- } \\
\text { der cancer. BJU Int 2001;88:686. } \\
\text { b Chinol M, De CO, Trifiro G, et al. Localization of avidin in superficial bladder cancer: A potentially new approach for ra- } \\
\text { dionuclide therapy. Eur Urol 2003;44:556. } \\
\text { 'Syrigos KN, Khawaja M, Krausz T, et al. Intravesical administration of radiolabelled tumour-associated monoclonal antibody } \\
\text { in bladder cancer. Acta Oncol 1999;38:379. } \\
\text { 'Kunkler RB, Bishop MC, Green DJ, et al. Targeting of bladder cancer with monoclonal antibody NCRC48-a possible ap- } \\
\text { proach for intravesical therapy. Br J Urol 1995;76:81. }\end{array}$} \\
\hline
\end{tabular}

\section{INTRAVESICAL RIT}

Bladder cancer is the second most common cancer of the genito-urinary system, mainly occurring in men. Two distinct types of urothelial cancer exist, the majority of which are superficial and noninvasive. However, the remaining 20\% are solid, highly aggressive bladder cancers that are invasive and metastasize in an early phase of the disease. ${ }^{94}$ Cystectomy is the treatment of choice for a tumor stage of T2-T4 (muscle invasive), leaving local resection to CIS and T1 disease. In T1 urothelial carcinoma recurrence rates are as high as $80 \%$ after resection. ${ }^{95}$ When intravesical chemotherapy is added to surgery, recurrence rates are reduced by $50 \%$ at 2 years. Part of the contemporary bladder-sparing treatment is the use of immunotherapy by means of an intravesical Bacille Calmette-Guérin (BCG) instillation, the results of which are comparable to those achieved with chemotherapy. ${ }^{96}$ Since the standard therapy in invasive bladder cancer is radical cystectomy, the role of RIT is limited to CIS and T1 disease.

Despite several preclinical experiments, reports on the clinical use of radiolabeled antibodies in patients with bladder cancer are limited to investigations on radioimmunoscintigraphy studies rather than RIT (see Table 4). In these studies, antibodies directed against the target antigen MUC-1 are used. MUC-1 mucin is a high-molecular-weight cell-surface glycoprotein that is found on normal urothelium and that is both unregulated as well as abnormally glycosylated in bladder cancer. ${ }^{97}$ One of the first studies in 20 patients was performed by Bamias et al., who intravesically administered the ${ }^{111}$ In-labeled anti-MUC-1 antibody HMFG2. ${ }^{98}$ Autoradiography of the resected specimen showed selective tumor targeting. Murray et al. used an intravesically administered ${ }^{188}$ Re-labeled C595 antibody in 3 patients with transitional cell carcinoma. ${ }^{99}$ In addition, this group investigated the intravesical administration of ${ }^{67} \mathrm{Cu}$-labeled $\mathrm{C} 595$ in 16 patients with bladder cancer and studied the systemic absorption of the radiolabeled antibody. ${ }^{100}$ The results of this study showed no detectable activity above the background, meaning there was no systemic radiolabel present after the local application, while $80 \%$ of the tumors were successfully visualized.

Malamitsi et al. investigated the intravesical application of ${ }^{99 \mathrm{~m}} \mathrm{Tc}-$ labeled MUC-1 antibody HMFG1 in 14 patients and concluded that, despite the excellent imaging of tumors, future attempts to administer RIT using HMFG1 should not be undertaken owing to a low and heteroge- 
neous uptake in the 6 patients with positive imaging (0\%-9\% injected dose) caused by heterogeneous antigen expression. ${ }^{101}$

In conclusion, intravesically administered RIS in bladder cancer may hold a promise for RIT, using anti-MUC1 antibodies, in early urothelial cell cancer owing to selective targeting and low systemic concentrations of the targeting agent.

\section{INTRATHORACIC RIT}

The prognosis of patients with malignant pleural mesothelioma (MPM) is poor. In general, median survival is $6-16$ months. The malignant form can be classified in two categories: diffuse or localized. Both are essentially insensitive to any treatment. ${ }^{102}$ Different agents for intracavitary chemotherapy to treat mesothelioma have been utilized. The response rate varied between $15 \%$ and $37 \%$, without effect on survival, even when used in combination with paclitaxel and docetaxel. The clinical data regarding studies that used intrathoracic chemotherapy adjuvant to surgical debulking were disappointing. ${ }^{103,104}$ Therefore, the intrathoracic application of chemotherapeutic agents is mainly used to treat malignant pleural effusion. ${ }^{105,106}$ Another obstacle for RIT of mesothelioma is the low tumor antigen (mesothelin, tenascin-c) expression. ${ }^{107}$ Enhancing antigen expression with proinflammatory cytokines, however, do not improve survival after immunotherapy. ${ }^{108}$

Mesothelin is a 40-kD cell-surface glycosylated phosphatidylinositol (GPI)-anchored glycoprotein, with functions in cell-to-cell adhesion expressed by normal mesothelial cells. It is highly overexpressed in cancers as malignant mesothelioma, pancreatic or ovarian carcinoma sarcomas, and in some gastrointestinal or pulmonary carcinomas. ${ }^{109}$ In preclinical studies, Hassan et al. and Fan et al. have used antimesothelin antibodies and antibody fragments linked to exotoxins to treat mesothelin-expressing tumors in nude mice. The development of experimental metastases was inhibited, and even a complete regression of the tumor was observed in some cases. ${ }^{110,111}$

In conclusion, this antigen may be an attractive target for the intrathoracic application of RIT, but no clinical RIT studies have been performed. Currently, a clinical trial is being conducted, using a chimeric mAb (MORAb-009) directed against a cell-surface glycoprotein, GP-9, that is overexpressed in epithelial type cancers as mesothelioma, ovarian, and pancreatic cancer.* GP-9 may, therefore, be a potentially suitable target for radiolabeled MORAb-009 in future RIT of MPM.

\section{Malignant pleural effusion (MPE)}

MPE is thought to arise from tumor emboli detaching from visceral tumor nodules and concomitant attachment to the parietal pleura. Also, direct tumor invasion (in lung cancers, chest wall neoplasms, and breast carcinoma), hematogenous spread to the parietal pleura, and lymphatic involvement may be a mechanism for development of MPE. The effusion is composed of extracellular matrix proteins, cytokines, and growth factors, thereby promoting cell proliferation and invasion. ${ }^{12}$ In women, the most common causes of these effusions are breast and ovarian cancer, whereas in men, these are lung cancer and malignant pleural mesothelioma. Treatment of this specific entity can be done by either therapeutical pleur aspiration (in case of a very short life expectancy), talc pleurodesis, or indwelling catheters. MPM with MPE is also an indication for intrapleural therapy, as is the case with MPE arising from ovarian cancer. Schmidt et al. described the successful intrapleural application of rituximab, an anti-CD20 $\mathrm{mAb}$, in a patient with NHL who was free of symptoms for 8 months after this treatment. ${ }^{113}$ The researchers described a case report regarding treatment failure of repeated percutaneous drainage and bilateral continuous chest tube drainage. This result may be promising, in particular when considering the possibilities of the effects of the application of radiolabeled antibodies. This is the case with ${ }^{90}$ Y-labeled ibritumomab tiuxetan for the treatment of NHL, where the RIC produces significantly better responses than the mAb alone. ${ }^{114}$

Awaiting the results of the trial using MORAb009 in the case of MPM and the future development of TAAs directed against MPM, there may be a role for RIT in the treatment of MPM. In addition, RIT may play a role in the palliative treatment in patients with MPE, regardless of the origin of the primary tumor.

\section{DISCUSSION}

The intracavitary application of radiolabeled antibodies combines the advantage of high tumor

*Source: Trial number: NCT00325494. www.clinicaltrials. gov Accessed January 28, 2008. 
doses and low systemic toxicity. Therefore, higher doses of RIT can be applied than with systemic administration.

Currently, RIT with radiolabeled anti-CD20 antibodies is an accepted treatment for patients with NHL. For other indications, only a limited number of clinical phase I/II and one phase III RIT trials have been performed, using different antibodies and radionuclides in patients with different types of cancer. The results various studies on the therapeutic efficacy and toxicity of RIT in patients with ovarian cancer $\left({ }^{90} \mathrm{Y}-\mathrm{HMFG}-1\right.$, $\left.{ }^{177} \mathrm{Lu}-\mathrm{B} 72.3\right)$ and malignant glioma $\left({ }^{131} \mathrm{I}-81 \mathrm{C} 6\right)$ indicate that the adjuvant application of RIT within a confined area limits toxicity and improves tumor targeting. In addition, RIT should be applied as a treatment of patients with minimal residual or microscopic disease of solid cancers in order to gain from its maximal potential.

For the treatment of ovarian cancer, the application of RIT was studied in a randomized, phase III trial. Unfortunately, the results of the latter study showed no survival benefit. The lack of efficacy of adjuvant RIT in this trial could be owing to several factors. First, the selection of the high-energy beta-emitter ${ }^{90} \mathrm{Y}$, with a maximum tissue penetration of $12 \mathrm{~mm}$, is not appropriate, since most of the energy will be deposited outside small tumor deposits in small-volume or microscopic disease. Second, the protein dose was augmented with $20 \mathrm{mg}$ of unlabeled antibody to a total of $25 \mathrm{mg}{ }^{90} \mathrm{Y}$-HMFG1, with the intent to provoke a human antimouse antibody response. This high antibody dose might have had a negative effect on the uptake of the radiolabel in the tumor lesions owing to the saturation of MUC-1 epitopes on the tumor cells. ${ }^{115}$ In the future, however, optimizing this treatment, using nuclides such as ${ }^{177} \mathrm{Lu}$ that are more suitable for minimal residual disease than ${ }^{90} \mathrm{Y}$ in order to enhance the antitumor effect, may result in survival benefit. The same can be true for the treatment of peritoneal carcinomatosis of colorectal origin when trials will be undertaken to treat this entity. Progress has been made in the treatment of recurrent glioma by the application of RIT and this treatment may, therefore, become an additional adjuvant treatment modality in neuro-oncology.

\section{CONCLUSIONS}

In the case of superficial bladder cancer, promising results of preclinical and radioimmuno- scintigraphy studies may precede phase I and II trials. When therapeutic options are no longer available, RIT may offer patients a chance of minimally invasive palliation in patients with MPM or MPE. The future of RIT may, therefore, not only be in the inclusion in contemporary multimodality treatment, but also in the expansion of its indication to palliative treatment as a supplement or even a substitution for present-day treatments.

\section{ACKNOWLEDGMENTS}

The authors wish to thank Professor Dr. André Grotenhuis (Department of Neurosurgery, Radboud University Nijmegen Medical Center Nijmegen, The Netherlands) for his valuable comments on earlier versions of this manuscript.

\section{REFERENCES}

1. Goyle S, Maraveyas A. Chemotherapy for colorectal cancer. Dig Surg 2005;22:401.

2. Yan T, Welch L, Black D, et al. A systematic review on the efficacy of cytoreductive surgery combined with perioperative intraperitoneal chemotherapy for diffuse malignancy peritoneal mesothelioma. Ann Oncol 2007; 18:827.

3. Fisher RI, Kaminski MS, Wahl RL, et al. Tositumomab and iodine-131 tositumomab produces durable complete remissions in a subset of heavily pretreated patients with low-grade and transformed non-Hodgkin's lymphomas. $\mathrm{J}$ Clin Oncol 2005;23:7565.

4. Davis TA, Kaminski MS, Leonard JP, et al. The radioisotope contributes significantly to the activity of radioimmunotherapy. Clin Cancer Res 2004;10:7792.

5. Gordon LI, Molina A, Witzig T, et al. Durable responses after ibritumomab tiuxetan radioimmunotherapy for CD20 ${ }^{+}$B-cell lymphoma: Long-term followup of a phase 1/2 study. Blood 2004;103:4429.

6. Kaanders JH, Bussink J, van der Kogel AJ. ARCON: A novel biology-based approach in radiotherapy. Lancet Oncol 2002;3:728.

7. Kaanders JH, Bussink J, van der Kogel AJ. Clinical studies of hypoxia modification in radiotherapy. Semin Radiat Oncol 2004;14:233.

8. Heldin CH. High interstitial fluid pressure - an obstacle in cancer therapy. Nat Rev Cancer 2004;4:806.

9. Koppe MJ, Soede AC, Pels W, et al. Experimental radioimmunotherapy of small peritoneal metastases of colorectal origin. Int J Cancer 2003;106:965.

10. Colcher D, Esteban J, Carrasquillo JA, et al. Complementation of intracavitary and intravenous administration of a monoclonal antibody (B72.3) in patients with carcinoma. Cancer Res 1987;47:4218. 
11. Kohler G, Milstein C. Continuous cultures of fused cells secreting antibody of predefined specificity. $\mathrm{Na}$ ture 1975;256:495.

12. Goldenberg DM, Sharkey RM. Advances in cancer therapy with radiolabeled monoclonal antibodies. $Q J$ Nucl Med Mol Imaging 2006;50:248.

13. Harris M. Monoclonal antibodies as therapeutic agents for cancer. Lancet Oncol 2004;5:292.

14. Lin MZ, Teitell MA, Schiller GJ. The evolution of antibodies into versatile tumor-targeting agents. Clin Cancer Res 2005;11:129.

15. Sharkey RM, Blumenthal RD, Behr TM, et al. Selection of radioimmunoconjugates for the therapy of wellestablished or micrometastatic colon carcinoma. Int J Cancer 1997;72:477.

16. Uusijarvi H, Bernhardt P, Rosch F, et al. Electron- and positron-emitting radiolanthanides for therapy: Aspects of dosimetry and production. $\mathrm{J} \mathrm{Nucl} \mathrm{Med} \mathrm{2006;}$ 47:807.

17. Shih LB, Thorpe SR, Griffiths GL, et al. The processing and fate of antibodies and their radiolabels bound to the surface of tumor cells in vitro: A comparison of nine radiolabels. $\mathrm{J} \mathrm{Nucl} \mathrm{Med} \mathrm{1994;35:899.}$

18. Koppe MJ, Bleichrodt RP, Soede AC, et al. Biodistribution and therapeutic efficacy of (125/131)I-, (186)Re-, (88/90)Y-, or (177)Lu-labeled monoclonal antibody MN-14 to carcinoembryonic antigen in mice with small peritoneal metastases of colorectal origin. J Nucl Med 2004;45:1224.

19. Novak-Hofer I, Schubiger PA. Copper-67 as a therapeutic nuclide for radioimmunotherapy. Eur J Nucl Med Mol Imaging 2002;29:821.

20. Yao V, Platell C, Hall JC. Role of peritoneal mesothelial cells in peritonitis. Br J Surg 2003;90:1187.

21. Dedrick RL, Flessner MF. Pharmacokinetic considerations on monoclonal antibodies. Prog Clin Biol Res 1989;288:429.

22. Flessner MF, Dedrick RL. Monoclonal antibody delivery to intraperitoneal tumors in rats: Effects of route of administration and intraperitoneal solution osmolality. Cancer Res 1994;54:4376.

23. van Ruth S, Verwaal VJ, Zoetmulder FA. Pharmacokinetics of intraperitoneal mitomycin C. Surg Oncol Clin N Am 2003;12:771.

24. Koppe MJ, Bleichrodt RP, Soede AC, et al. Biodistribution and therapeutic efficacy of (125/131)I-, (186)Re-, (88/90)Y-, or (177)Lu-labeled monoclonal antibody MN-14 to carcinoembryonic antigen in mice with small peritoneal metastases of colorectal origin. J Nucl Med 2004;45:1224.

25. Koppe MJ, Soede AC, Pels W, et al. Experimental radioimmunotherapy of small peritoneal metastases of colorectal origin. Int J Cancer 2003;106:965.

26. van Zanten-Przybysz I, Molthoff CF, Roos JC, et al. Influence of the route of administration on targeting of ovarian cancer with the chimeric monoclonal antibody MOv18: i.v. vs. i.p. Int J Cancer 2001;92:106.

27. Dubeau L. The cell of origin of ovarian epithelial tumors and the ovarian surface epithelium dogma: Does the emperor have no clothes? Gynecol Oncol 1999; 72:437.

28. Bhoola S, Hoskins WJ. Diagnosis and management of epithelial ovarian cancer. Obstet Gynecol 2006;107: 1399.

29. Ozols RF. Systemic therapy for ovarian cancer: Current status and new treatments. Semin Oncol 2006; 33:S3.

30. Rubin SC. Monoclonal antibodies in the management of ovarian cancer. A clinical perspective. Cancer 1993;71:1602.

31. Haisma HJ, Moseley KR, Battaile AI, et al. Biodistribution, pharmacokinetics, and imaging of ${ }^{131} \mathrm{I}$-labelled OC125 in ovarian cancer. Int J Cancer Suppl 1988; 2:109.

32. Buijs WC, Tibben JG, Boerman OC, et al. Dosimetric analysis of chimeric monoclonal antibody cMOv18 $\mathrm{IgG}$ in ovarian carcinoma patients after intraperitoneal and intravenous administration. Eur J Nucl Med 1998; 25:1552.

33. Kalofonos HP, Karamouzis MV, Epenetos AA. Radioimmunoscintigraphy in patients with ovarian cancer. Acta Oncol 2001;40:549.

34. Epenetos AA, Munro AJ, Stewart S, et al. Antibodyguided irradiation of advanced ovarian cancer with intraperitoneally administered radiolabeled monoclonal antibodies. J Clin Oncol 1987;5:1890.

35. Nicholson S, Gooden CS, Hird V, et al. Radioimmunotherapy after chemotherapy compared to chemotherapy alone in the treatment of advanced ovarian cancer: A matched analysis. Oncol Rep 1998;5:223.

36. Epenetos AA, Hird V, Lambert H, et al. Long-term survival of patients with advanced ovarian cancer treated with intraperitoneal radioimmunotherapy. Int J Gynecol Cancer 2000;10:44.

37. Verheijen RH, Massuger LF, Benigno BB, et al. Phase III trial of intraperitoneal therapy with yttrium-90-labeled HMFG1 murine monoclonal antibody in patients with epithelial ovarian cancer after a surgically defined complete remission. J Clin Oncol 2006;24:571.

38. Massuger LF, Verheijen RH, Seiden MV. Intraperitoneal disease control after i.p. concolidation treatment with yttrium-90-labeled HMFG1 monoclonal antibody in patients with epithelial ovarian cancer. Annual Meeting on Women's Cancer of the Society of Gynecologic Oncologists, Miami Beach, FL, March 19-23, 2005.

39. Rosenblum MG, Kavanagh JJ, Burke TW, et al. Clinical pharmacology, metabolism, and tissue distribution of ${ }^{90} \mathrm{Y}$-labeled monoclonal antibody B72.3 after intraperitoneal administration. J Natl Cancer Inst 1991; $83: 1629$.

40. Meredith RF, Partridge EE, Alvarez RD, et al. Intraperitoneal radioimmunotherapy of ovarian cancer with lutetium-177-CC49. J Nucl Med 1996;37:1491.

41. Rosenblum MG, Verschraegen CF, Murray JL, et al. Phase I study of ${ }^{90} \mathrm{Y}$-labeled B72.3 intraperitoneal administration in patients with ovarian cancer: Effect of dose and EDTA coadministration on pharmacokinetics and toxicity. Clin Cancer Res 1999;5:953. 
42. Alvarez RD, Partridge EE, Khazaeli MB, et al. Intraperitoneal radioimmunotherapy of ovarian cancer with ${ }^{177}$ Lu-CC49: A phase I/II study. Gynecol Oncol 1997;65:94.

43. Roselli M, Guadagni F, Buonomo O, et al. Systemic administration of recombinant interferon alfa in carcinoma patients upregulates the expression of the carcinoma-associated antigens tumor-associated glycoprotein-72 and carcinoembryonic antigen. $\underline{J \text { Clin Oncol }}$ 1996;14:2031.

44. Meredith RF, Alvarez RD, Partridge EE, et al. Intraperitoneal radioimmunochemotherapy of ovarian cancer: A phase I study. Cancer Biother Radiopharm 2001;16:305.

45. Miotti S, Facheris P, Tomassetti A, et al. Growth of ovarian-carcinoma cell lines at physiological folate concentration: Effect on folate-binding protein expression in vitro and in vivo. Int J Cancer 1995;63:395.

46. Crippa F, Bolis G, Seregni E, et al. Single-dose intraperitoneal radioimmunotherapy with the murine monoclonal antibody I-131 MOv18: Clinical results in patients with minimal residual disease of ovarian cancer. Eur J Cancer 1995;31A:686.

47. Mahe MA, Fumoleau P, Fabbro M, et al. A phase II study of intraperitoneal radioimmunotherapy with iodine-131-labeled monoclonal antibody OC-125 in patients with residual ovarian carcinoma. Clin Cancer Res 1999;5:3249s.

48. O'Brien TJ, Tanimoto H, Konishi I, et al. More than 15 years of CA 125: What is known about the antigen, its structure, and its function. Int J Biol Markers $1998 ; 13: 188$

49. Haisma HJ, Battaile A, Stradtman EW, et al. Antibodyantigen complex formation following injection of OC125 monoclonal antibody in patients with ovarian cancer. Int J Cancer 1987;40:758.

50. Koppe MJ, Boerman OC, Oyen WJ, et al. Peritoneal carcinomatosis of colorectal origin: Incidence and current treatment strategies. Ann Surg 2006;243:212.

51. Jayne DG, Fook S, Loi $\mathrm{C}$, et al. Peritoneal carcinomatosis from colorectal cancer. Br J Surg 2002;89: 1545.

52. Glehen O, Cotte E, Schreiber V, et al. Intraperitoneal chemohyperthermia and attempted cytoreductive surgery in patients with peritoneal carcinomatosis of colorectal origin. Br J Surg 2004;91:747.

53. Culliford AT, Brooks AD, Sharma S, et al. Surgical debulking and intraperitoneal chemotherapy for established peritoneal metastases from colon and appendix cancer. Ann Surg Oncol 2001;8:787.

54. Glehen O, Kwiatkowski F, Sugarbaker PH, et al. Cytoreductive surgery combined with perioperative intraperitoneal chemotherapy for the management of peritoneal carcinomatosis from colorectal cancer: A multi-institutional study. J Clin Oncol 2004;22:3284.

55. Elias D, Blot F, El OA, et al. Curative treatment of peritoneal carcinomatosis arising from colorectal cancer by complete resection and intraperitoneal chemotherapy. Cancer 2001;92:71.
56. Meredith RF, Khazaeli MB, Liu T, et al. Dose fractionation of radiolabeled antibodies in patients with metastatic colon cancer. $\mathrm{J} \mathrm{Nucl} \mathrm{Med} \mathrm{1992;33:1648.}$

57. Koppe MJ, Bleichrodt RP, Oyen WJ, et al. Radioimmunotherapy and colorectal cancer. Br J Surg 2005; 92:264.

58. Riva P, Tison V, Arista A, et al. Radioimmunotherapy of gastrointestinal cancer and glioblastomas. Int J Biol Markers 1993;8:192.

59. Keenan AM, Colcher D, Larson SM, et al. Radioimmunoscintigraphy of human colon cancer xenografts in mice with radioiodinated monoclonal antibody B72.3. J Nucl Med 1984;25:1197.

60. Koppe MJ, Soede AC, Pels W, et al. Experimental radioimmunotherapy of small peritoneal metastases of colorectal origin. Int J Cancer 2003;106:965.

61. Koppe MJ, Bleichrodt RP, Soede AC, et al. Biodistribution and therapeutic efficacy of (125/131)I-, (186)Re-, (88/90)Y-, or (177)Lu-labeled monoclonal antibody MN-14 to carcinoembryonic antigen in mice with small peritoneal metastases of colorectal origin. J Nucl Med 2004;45:1224.

62. Koppe MJ, Hendriks T, Boerman OC, et al. Radioimmunotherapy is an effective adjuvant treatment modality after cytoreductive surgery of peritoneal carcinomatosis of colonic origin. J Nucl Med 2006;47:1867.

63. Reardon DA, Rich JN, Friedman HS, et al. Recent advances in the treatment of malignant astrocytoma. $\underline{J}$ Clin Oncol 2006;24:1253.

64. Ohgaki H, Dessen P, Jourde B, et al. Genetic pathways to glioblastoma: A population-based study. Cancer Res 2004;64:6892.

65. Brooks DJ, Beaney RP, Lammertsma AA, et al. Quantitative measurement of blood-brain barrier permeability using rubidium- 82 and positron emission tomography. J Cereb Blood Flow Metab 1984;4:535.

66. Vajkoczy P, Menger MD. Vascular microenvironment in gliomas. Cancer Treat Res 2004;117:249.

67. Evans SM, Judy KD, Dunphy I, et al. Hypoxia is important in the biology and aggression of human glial brain tumors. Clin Cancer Res 2004;10:8177.

68. Jain RK. Delivery of molecular medicine to solid tumors: Lessons from in vivo imaging of gene expression and function. $\mathrm{J}$ Contr Rel 2001;74:7.

69. Burger PC, Vogel FS, Green SB, et al. Glioblastoma multiforme and anaplastic astrocytoma. Pathologic criteria and prognostic implications. Cancer 1985; 56:1106.

70. Kleihues P, Sobin LH. World Health Organization classification of tumors. Cancer 2000;88:2887.

71. Souhami L, Seiferheld W, Brachman D, et al. Randomized comparison of stereotactic radiosurgery followed by conventional radiotherapy with carmustine to conventional radiotherapy with carmustine for patients with glioblastoma multiforme: report of Radiation Therapy Oncology Group 93-05 protocol. Int J Radiat Oncol Biol Phys 2004;60:853.

72. Selker RG, Shapiro WR, Burger P, et al. The Brain Tumor Cooperative Group NIH Trial 87-01: A ran- 
domized comparison of surgery, external radiotherapy, and carmustine versus surgery, interstitial radiotherapy boost, external radiation therapy, and carmustine. $\mathrm{Neu}$ rosurgery 2002;51:343.

73. Stupp R, Mason WP, van den Bent MJ, et al. Radiotherapy plus concomitant and adjuvant temozolomide for glioblastoma. $\mathrm{N} \mathrm{Engl} \mathrm{J} \mathrm{Med} \mathrm{2005;352:987.}$

74. Arismendi-Morillo G, Castellano A. Tumoral microblood vessels and vascular microenvironment in human astrocytic tumors. A transmission electron microscopy study. J Neurooncol 2005;73:211.

75. Schold SC, Jr, Zalutsky MR, Coleman RE, et al. Distribution and dosimetry of I-123-labeled monoclonal antibody 81C6 in patients with anaplastic glioma. Invest Radiol 1993;28:488.

76. Guerin C, Olivi A, Weingart JD, et al. Recent advances in brain tumor therapy: Local intracerebral drug delivery by polymers. Invest New Drugs 2004;22:27.

77. Hsia HC, Schwarzbauer JE. Meet the tenascins: Multifunctional and mysterious. $\mathrm{J} \mathrm{Biol} \mathrm{Chem} \mathrm{2005;280:}$ 26641.

78. Zagzag D, Friedlander DR, Dosik J, et al. Tenascin-C expression by angiogenic vessels in human astrocytomas and by human brain endothelial cells in vitro. Cancer Res 1996;56:182.

79. McLendon RE, Wikstrand CJ, Matthews MR, et al. Glioma-associated antigen expression in oligodendroglial neoplasms. Tenascin and epidermal growth factor receptor. J Histochem Cytochem 2000;48:1103.

80. Kim $\mathrm{CH}$, Bak $\mathrm{KH}$, Kim YS, et al. Expression of tenascin-C in astrocytic tumors: Its relevance to proliferation and angiogenesis. Surg Neurol 2000;54:235.

81. Bigner DD, Brown MT, Friedman AH, et al. Iodine131-labeled antitenascin monoclonal antibody 81C6 treatment of patients with recurrent malignant gliomas: Phase I trial results. J Clin Oncol 1998;16:2202.

82. Akabani G, Cokgor I, Coleman RE, et al. Dosimetry and dose-response relationships in newly diagnosed patients with malignant gliomas treated with iodine131-labeled anti-tenascin monoclonal antibody 81C6 therapy. Int J Radiat Oncol Biol Phys 2000;46:947.

83. Cokgor I, Akabani G, Kuan CT, et al. Phase I trial results of iodine-131-labeled antitenascin monoclonal antibody 81C6 treatment of patients with newly diagnosed malignant gliomas. J Clin Oncol 2000;18:3862.

84. Reardon DA, Akabani G, Coleman RE, et al. Phase II trial of murine (131)I-labeled antitenascin monoclonal antibody 81C6 administered into surgically created resection cavities of patients with newly diagnosed malignant gliomas. J Clin Oncol 2002;20:1389.

85. Reardon DA, Akabani G, Coleman RE, et al. Salvage radioimmunotherapy with murine iodine-131-labeled antitenascin monoclonal antibody 81C6 for patients with recurrent primary and metastatic malignant brain tumors: Phase II study results. J Clin Oncol 2006;24:115.

86. Reardon DA, Quinn JA, Akabani G, et al. Novel human $\mathrm{IgG} 2 \mathrm{~b} /$ murine chimeric antitenascin monoclonal antibody construct radiolabeled with ${ }^{131} \mathrm{I}$ and administered into the surgically created resection cavity of patients with malignant glioma: Phase I trial results. $\underline{J}$ Nucl Med 2006;47:912.

87. Riva P, Arista A, Sturiale C, et al. Treatment of intracranial human glioblastoma by direct intratumoral administration of ${ }^{131}$ I-labeled anti-tenascin monoclonal antibody BC-2. Int J Cancer 1992;51:7.

88. Riva P, Arista A, Tison V, et al. Intralesional radioimmunotherapy of malignant gliomas. An effective treatment in recurrent tumors. Cancer 1994;73:1076.

89. Riva P, Arista A, Franceschi G, et al. Local treatment of malignant gliomas by direct infusion of specific monoclonal antibodies labeled with ${ }^{131} \mathrm{I}$ : Comparison of the results obtained in recurrent and newly diagnosed tumors. Cancer Res 1995;55:5952s.

90. Riva P, Franceschi G, Frattarelli M, et al. ${ }^{131}$ I radioconjugated antibodies for the locoregional radioimmunotherapy of high-grade malignant glioma-phase I and II study. Acta Oncol 1999;38:351.

91. Riva P, Franceschi G, Frattarelli M, et al. Locoregional radioimmunotherapy of high-grade malignant gliomas using specific monoclonal antibodies labeled with ${ }^{90} \mathrm{Y}$ : A phase I study. Clin Cancer Res 1999;5:3275s.

92. Paganelli G, Bartolomei M, Ferrari M, et al. Pretargeted locoregional radioimmunotherapy with ${ }^{90} \mathrm{Y}$-biotin in glioma patients: Phase I study and preliminary therapeutic results. Cancer Biother Radiopharm 2001; 16:227.

93. Paganelli G, Grana C, Chinol M, et al. Antibodyguided three-step therapy for high grade glioma with yttrium-90 biotin. Eur J Nucl Med 1999;26:348.

94. Dinney CP. Therapy of invasive bladder cancer. Urology 2006;67:56.

95. Nieder AM, Brausi M, Lamm D, et al. Management of stage T1 tumors of the bladder: International Consensus Panel. Urology 2005;66:108.

96. Shelley MD, Court JB, Kynaston H, et al. Intravesical Bacillus Calmette-Guerin versus Mitomycin C for Ta and T1 Bladder Cancer. Cochrane Database Syst Rev 2003;3:CD003231

97. Walsh MD, Hohn BG, Thong W, et al. Mucin expression by transitional cell carcinomas of the bladder. Br J Urol 1994;73:256.

98. Bamias A, Bowles MJ, Krausz T, et al. Intravesical administration of indium-111-labelled HMFG2 monoclonal antibody in superficial bladder carcinomas. Int J Cancer 1993;54:899.

99. Murray A, Simms MS, Scholfield DP, et al. Production and characterization of 188Re-C595 antibody for radioimmunotherapy of transitional cell bladder cancer. $\mathrm{J} \mathrm{Nucl} \mathrm{Med} \mathrm{2001;42:726.}$

100. Hughes OD, Bishop MC, Perkins AC, et al. Targeting superficial bladder cancer by the intravesical administration of copper-67-labeled anti-MUC1 mucin monoclonal antibody C595. J Clin Oncol 2000;18:363.

101. Malamitsi J, Zorzos J, Varvarigou AD, et al. Immunolocalization of transitional cell carcinoma of the bladder with intravesically administered technetium99m labelled HMFG1 monoclonal antibody. Eur J Nucl Med 1995;22:25. 
102. Sterman DH, Kaiser LR, Albelda SM. Advances in the treatment of malignant pleural mesothelioma. Chest 1999;116:504.

103. van Ruth S, Baas P, Haas RL, et al. Cytoreductive surgery combined with intraoperative hyperthermic intrathoracic chemotherapy for stage I malignant pleural mesothelioma. Ann Surg Oncol 2003;10:176.

104. van Ruth S, van TO, Korse CM, et al. Pharmacokinetics of doxorubicin and cisplatin used in intraoperative hyperthermic intrathoracic chemotherapy after cytoreductive surgery for malignant pleural mesothelioma and pleural thymoma. Anticancer Drugs 2003;14:57.

105. Kasahara K, Shibata K, Shintani H, et al. Randomized, phase II trial of OK-432 in patients with malignant pleural effusion due to non-small-cell lung cancer. $A n$ ticancer Res 2006;26:1495.

106. Eitan R, Levine DA, bu-Rustum N, et al. The clinical significance of malignant pleural effusions in patients with optimally debulked ovarian carcinoma. Cancer 2005;103:1397.

107. Fitzpatrick DR, Peroni DJ, Bielefeldt-Ohmann H. The role of growth factors and cytokines in the tumorigenesis and immunobiology of malignant mesothelioma. Am J Respir Cell Mol Biol 1995;12:455.

108. Robinson BW, Lake RA. Advances in malignant mesothelioma. N Engl J Med 2005;353:1591.

109. Scherpereel A, Grigoriu B, Conti M, et al. Soluble mesothelin-related peptides in the diagnosis of malig- nant pleural mesothelioma. Am J Respir Crit Care Med 2006; 173:1155.

110. Hassan R, Viner JL, Wang QC, et al. Anti-tumor activity of K1-LysPE38QQR, an immunotoxin targeting mesothelin, a cell-surface antigen overexpressed in ovarian cancer and malignant mesothelioma. $\mathrm{J} \mathrm{Im-}$ munother 2000;23:473.

111. Fan D, Yano S, Shinohara H, et al. Targeted therapy against human lung cancer in nude mice by high-affinity recombinant antimesothelin single-chain Fv immunotoxin. Mol Cancer Ther 2002;1:595.

112. Lynch CC, Matrisian LM. Matrix metalloproteinases in tumor-host cell communication. Differentiation 2002;70:561.

113. Schmidt HH, Renner H, Lïnkesch W. Intrapleural instillation of rituximab for the treatment of malignant pleural effusions in NHL. Haematologica 2004;89: ECR39.

114. Witzig TE, Gordon LI, Cabanillas F, et al. Randomized, controlled trial of yttrium-90-labeled ibritumomab tiuxetan radioimmunotherapy versus rituximab immunotherapy for patients with relapsed or refractory low-grade, follicular, or transformed B-cell non-Hodgkin's lymphoma. $J$ Clin Oncol 2002;20:2453.

115. Kranenborg MH, Boerman OC, de Weijert MC, et al. The effect of antibody protein dose of anti-renal cell carcinoma monoclonal antibodies in nude mice with renal cell carcinoma xenografts. $\underline{\text { Cancer }}$ 1997;80:2390. 
This article has been cited by:

1. Csilla Hasovits, Stephen Clarke. 2012. Pharmacokinetics and Pharmacodynamics of Intraperitoneal Cancer Chemotherapeutics. Clinical Pharmacokinetics 51:4, 203-224. [CrossRef]

2. Robert M Sharkey, David M Goldenberg. 2011. Cancer radioimmunotherapy. Immunotherapy 3:3, 349-370. [CrossRef]

3. Nobuyuki Kosaka, Mikako Ogawa, David S. Paik, Chang H. Paik, Peter L. Choyke, Hisataka Kobayashi. 2010. Semiquantitative assessment of the microdistribution of fluorescence-labeled monoclonal antibody in small peritoneal disseminations of ovarian cancer. Cancer Science 101:3, 820-825. [CrossRef] 